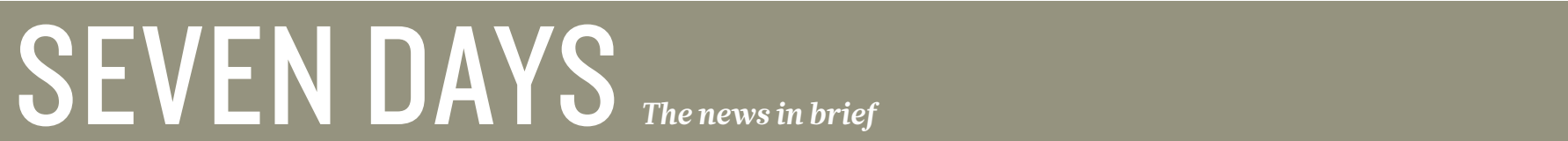

POLICY

\section{Nuclear-free Japan}

Japan's last operating nuclear reactor was switched off on 5 May, leaving the country entirely without nuclear power. The reactor, at the Tomari nuclear power plant in Hokkaido, was taken offline for routine maintenance. None of the reactors that were closed down after an earthquake and tsunami struck the Fukushima Daiichi plant last March has yet reopened. It is not clear when or if any of Japan's 50 functional reactors will go back online; some have passed official safety tests, but face suspicion from local residents. See go.nature. com/dld2nz for more.

\section{Fracking rules}

The US Department of the Interior's Bureau of Land Management released a draft on 4 May of rules that would require companies to disclose the chemicals they use in hydraulic fracturing or 'fracking', which involves pumping fluid into rocks to release natural gas and oil. The technique has provoked public protest, in part because of fears that chemicals used in the process could pollute ground water. See go.nature.com/ ozuqd2 for more.

\section{Failed drugs review}

A cache of at least 24 drugs abandoned during development by three major pharmaceutical companies will become available to scientists seeking new therapeutic uses for them under a US $\$ 20$ million competitive grants programme, the US National Institutes of Health (NIH) announced on 3 May. The pilot programme, with Pfizer, AstraZeneca and Eli Lilly, is running through the NIH's National Center for Advancing Translational Sciences, which was established this year. A

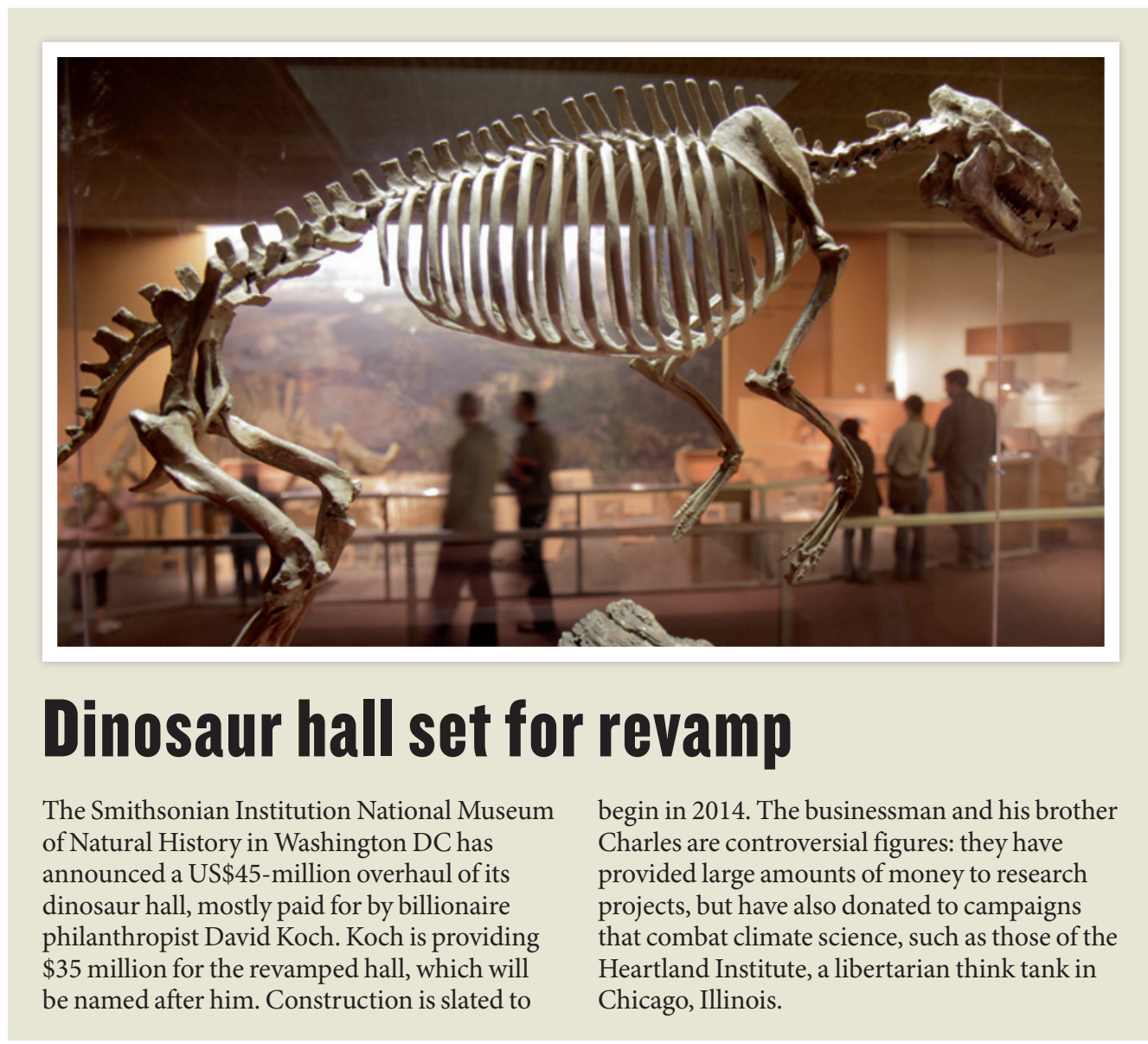

similar collaboration, between Astrazeneca and the UK Medical Research Council, was launched last December. See go.nature.com/o4gjtl for more.

\section{South Korea carbon}

Building on an ambitious effort to invest in green technologies and reduce reliance on imported fossil fuels, South Korea has become the first Asian nation to formally adopt a cap-andtrade programme to reduce greenhouse-gas emissions. The programme, approved on 2 May, starts in 2015 and would cover around 60\% of national emissions. The country has committed to reducing its 2020 'businessas-usual' projected emissions by $30 \%$. See go.nature.com/ iouadq for more.

\section{Bio-pharming}

The US Food and Drug Administration approved on 2 May its first biological drug produced in a genetically engineered plant cell. The drug, Elelyso (taliglucerase alfa), is made by biotech company Protalix Biotherapeutics based in Carmiel, Israel, to treat Gaucher's disease, a hereditary enzyme-deficiency disorder. See page 160 for more.

\section{Drug-marketing fine}

US pharmaceutical company Abbott Laboratories will pay US $\$ 1.6$ billion in connection with its illegal marketing of an anti-seizure drug, Depakote (divalproex sodium). The company, which is headquartered in Abbott Park, Illinois, and the US Department of Justice announced the settlement on 7 May, ending a fouryear investigation. Abbott marketed the medication for uses not approved by the US Food and Drug Administration, including schizophrenia and agitated dementia.

\section{PEOPLE}

\section{Physicist sentenced}

French-Algerian physicist Adlène Hicheur has been sentenced to four years in prison - and a further oneyear suspended sentence - after being found guilty of plotting with al-Qaeda's North African branch to carry out terror attacks on French 


\begin{abstract}
of soil. Supporters said that his sentencing on 4 May was a 동 miscarriage of justice. Hicheur has been in custody since he was detained in 2009, when he was a postdoc in high-energy physics at the Swiss Federal Institute of Technology in Lausanne. With time already spent in prison, and term reductions available under France's judicial system, he is likely to be released soon. See go.nature.com/s2wz9x for more.
\end{abstract}

\section{Lab death}

A 25-year-old lab worker who was studying Neisseria meningitidis died on 28 April, apparently from an infection with the bacterium. Richard Din was researching vaccines against subtype $B$ of $N$. meningitidis (a strain for which there is no effective vaccine) at the Veterans Affairs Medical Center in San Francisco, California. The news was revealed on 2 May; state and federal health and safety officials are investigating Din's death. See go.nature.com/ w2v6uc for more.

\section{Science chief leaves}

Bruce Alberts will depart his post as editor-in-chief of the journal Science by March 2013, said its publisher, the American Association for the Advancement of Science in Washington DC, on 3 May. Alberts (pictured) is professor

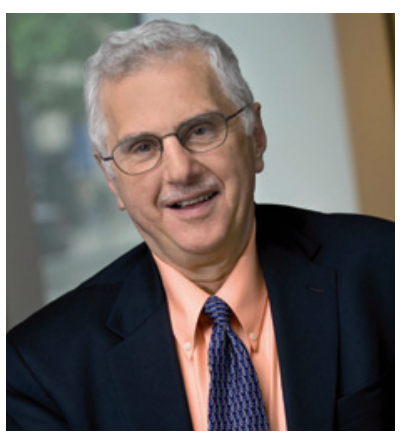

emeritus of biochemistry and biophysics at the University of California, San Francisco, and became the 18th editor-inchief of the journal in 2008. See go.nature.com/r7eiqi for more.

\section{Retiring president}

The US National Academy of Engineering (NAE) president Charles Vest, a mechanical engineer who took office in 2007, will step down next year and not serve a second six-year term, the academy confirmed last week. The organization is looking for a successor. Before his stint at the NAE, Vest was president of the Massachusetts Institute of Technology in Cambridge for 14 years.

\section{German plagiarism}

\section{German research minister}

Annette Schavan is the latest target in the country's recent rash of plagiarism accusations against high-level politicians. The University of Düsseldorf is investigating accusations posted on an anonymous webpage on 2 May that Schavan had inadequately cited original sources in her 1980 thesis on moral education. Some experts say that the extent of the alleged plagiarism is minor and have called for a formal, independent body to assess future allegations to avoid witch-hunts.

\section{New to US academy}

Among the 84 members elected to the US National Academy of Sciences on 2 May were Karl Deisseroth, an optogenetics researcher at Stanford University in California, and planetary scientist Robin Canup of the Southwest Research Institute in Boulder, Colorado. In total, the academy elected 26 women as members - the most it has ever admitted in one year. The academy also added 21 foreign associates; it now has 2,152 active members and 430 foreign associates. See go.nature.com/onztjx for more.

\section{RESEARCH}

\section{Jupiter mission}

The European Space Agency (ESA) has approved a roughly $€ 1$-billion (US\$1.3billion) mission to Jupiter and its moons, scheduled to launch in 2022. On 2 May, ESA's Science Programme Committee endorsed the Jupiter Icy moons Explorer,

\section{TREND WATCH}

Five years ago, a decadal survey of the United States' space-based environmental-monitoring programme by the National Research Council (NRC) found that its satellite system was "at risk of collapse". In a 2 May study, the NRC says that the outlook is worse: rising costs and the launch failures of NASA's Orbiting Carbon Observatory (February 2009) and Glory satellite (March 2011) mean the US Earthobserving system is beginning a "rapid decline in capability". See go.nature.com/p6xxhv for more.

\section{UNITED STATES TO LOSE EARTH-OBSERVING POWER}

Delays, mission changes and budgetary woes mean a steep decline for US satellite missions to observe Earth.

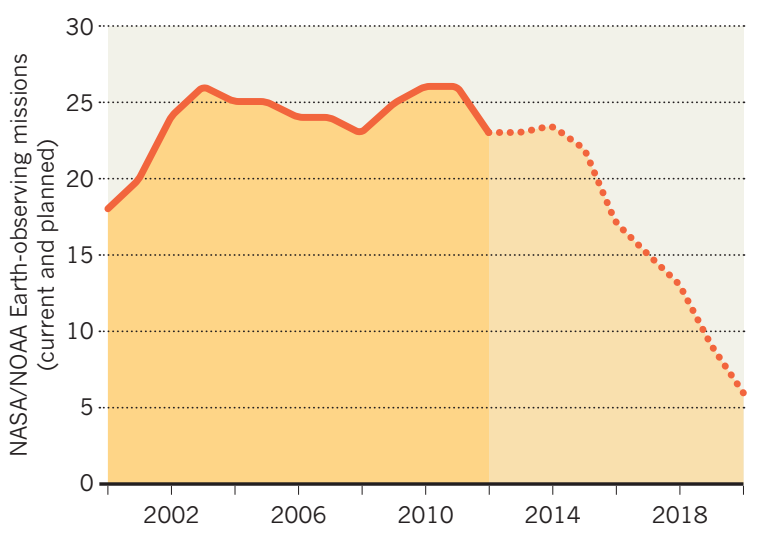

COMING UP

14-15 MAY

The US National Institutes of Health hosts a summit to discuss the latest research on Alzheimer's disease, in Bethesda, Maryland. go.nature.com/eo9nyp

\section{4-15 MAY}

In Washington DC, the US National Science Foundation hosts a global summit to discuss principles and procedures for peer review.

or JUICE, as its next 'large class' space probe. The 11-year mission would explore Jupiter's aurora and hunt for liquid oceans beneath the surfaces of the moons Ganymede and Europa. JUICE was picked over two other missions - the spacebased New Gravitational wave Observatory, and an X-ray telescope called ATHENA. See go.nature.com/lrvyl2 and page 148 for more.

\section{Cancer-genome hub}

The University of California, Santa Cruz, has opened a US\$10.3-million cancergenomics repository for data from the three major US cancer-sequencing projects: the Cancer Genome Atlas, the Therapeutically Applicable Research to Generate Effective Treatments project and the Cancer Genome Characterization Initiative. That makes the database the largest collection of cancer genomes accessible to researchers around the world. Aggregating the data into one place is key to advancing the use of personal genomics technologies in cancer, says project leader David Haussler. See go.nature.com/xhnj9l for more.

\section{$\rightarrow$ NATURE.COM}

For daily news updates see: www.nature.com/news 